\title{
Pro - Kontra Pemulangan Warga Negara Indonesia Eks Islamic State In Iraq And Syria
}

\author{
Abdurrahman Hakim \\ Pascasarjana Institut Agama Islam Negeri Tulungagung \\ E-mail: Cakman1996@yahoo.com
}

\begin{abstract}
Abstrak
Penelitian ini bertujuan untuk menganalisis kebijakan pemerintah yang memutuskan untuk tidak memulangkan kembali warga negara Indonesia mantan simpatisan oraganisasi terorisme Negara Islam Irak dan Suriah (ISIS). Teori yang dipakai untuk analisis kasus tersebut adalah teori maqashid al-syari'ah Jasser Auda dan teori tentang penegakan hukum hak asasi manusia. Metode penelitian yang dipakai adalah kualitatif - deskriptif dengan jenis penelitian pustaka. Sumber datanya berupa surat kabar, undang-undang, buku, dan jurnal. Hasil penelitian ini adalah semua simpatisan Islamic State of Iraq and Syria tidak bisa kategorikan sebagai palaku terorisme. Anak-anak dan istri merupakan korban dari doktrin kepala keluarga. Bagi pelaku terorisme, tidak memulangkan pelaku terorisme adalah keputusan yang tepat, tapi untuk anak - anak dan istri, pemerintah seharusnya tidak memberi tindakan yang sama. Untuk itu peneliti menawarkan upaya deradikalisasi bagi pelaku terorisem jika nantinya pemerintah memberi izin untuk kembali ke Indonesia.
\end{abstract}

Kata kunci: ISIS, Maqashid al-Syari'ah, Hak Asasi Manusia, Deradikalisasi

\begin{abstract}
This research aims to analyze government policies that decide not to repatriate former Indonesian citizens of Islamic State in Iraq And Syria (ISIS). The theory used for the analysis of these cases is the theory of maqasid shariah Jasser Auda and the theory of law enforcement on human rights. The research method used is descriptive qualitative with the type of library research. Data sources include newspapers, laws, books, and journals. The results of this research are all sympathizers of the Islamic State in Iraq and Syria cannot be called terrorism. Children and women are victims of the doctrine of their family heads. For terrorists, not repatriating them is the right decision, but for their children and wives, the government should not take the same action. For this reason, the researcher offers them a deradicalization effort if the government later allows them to return to Indonesia.
\end{abstract}

Keywords: ISIS, Maqashid Shariah, Human Right, Deradicalization. 


\section{A. Pendahuluan}

Pasca dinyatakan kalah pada tahun 2019, muncul permasalahan baru yaitu bagaimana nasib mantan simpatisan Islamic State of Iraq and Syria (ISIS) yang masih tersisa. Pasalnya, tidak semua simpatisan ISIS berasal dari Iraq dan Suriah, banyak pula yang berasal dari negara - negara berpenduduk muslim, salah satunya dari Indonesia. Hingga bulan Februari 2020, pemerintah mencatat ada sekitar 687 orang dari mereka berstatus sebagai warga negara Indonesia, yang terdiri dari pria dewasa, perempuan, bahkan anak-anak. ${ }^{1}$

Merespon hal tersebut, pemerintah awalnya berencana memulangkan simpatisan tersebut. Namun, ada penolakan dari berbagai kelompok masyarakat di Indonesia. Penolakan yang paling keras berasal dari keluarga korban kasus terorisme yang pernah terjadi di Indonesia. Seperti bom Bali tahun 2002, bom Thamrin, rencana serangan pos polisi di Tanggerang, jaringan Majalengka, bom Mapolresta Surakarta dan Teror 17 Agustus di Solo pada $2015 .^{2}$

ISIS merupakan organisasi teroris internasional yang dipimpin Abu Bakar al - Baghdadi. Organisasi tersebut dikenal dengan istilah "Islam garis keras". Stigma negatif Barat terhadap Islam salah satunya adalah akibat perilaku keras, diskriminatif, dan menyuarakan jihad dengan cara pembunuhan terhadap non - muslim.

Pemulangan eks ISIS terhalang oleh kebijakan deradikalisasi yang menjadi program pemerintah dalam menekan ideologi radikal di Indonesia. Deradikalisasi bertujuan untuk mencegah paham reaktif di masyarakat akibat propaganda ketidakadilan oleh oknum - oknum tertentu. Sehingga, jika eks ISIS tetap dipulangkan, maka untuk mensukseskan deradikalisasi akan

${ }^{1}$ Andika Prastia, Tok! Pemerintah Tak Akan Pulangkan WNI eks ISIS, news.detik.com/berita/d-4894943/tok-pemerintah-tak-akan-pulangkan-wni-eks-isis, tanggal akses 11 April 2020.

${ }^{2}$ Yus Ariyanto, 5 jejak ISIS di Indonesia, https://www.liputan6.com/news/read, tanggal akses 21 April 2020. 
menemui kegagalan. Hal ini karena objek deradikalisasi adalah pemuda pemuda yang masih memiliki pemahaman ideologi yang sesuai dengan Pancasila. Jika mengacu pada teori asal deradikalisasi, seharusnya upaya ini tidak diguakan sebagai pencegahan saja, tapi juga rekonstruksi pemikiran.

Keputusan akhir pemerintah untuk tidak memulangkan WNI tersebut menuai banyak kritikan. Salah satunya dari Komisi Nasional Hak Asasi Manusia (KOMNAS HAM). Ketua Komnas HAM, Ahmad Taufan menyarankan pemerintah agar tidak mengaggap semua sama. Harus ada pendataan yang melibatkan BNPT untuk mengetahui secara jelas profil setiap WNI. Sebaiknya pemerintah menerapkan Pasal 26B yaitu memberi hukuman penjara antara $7-12$ tahun. $^{3}$

Penelitian ini penting karena ada inkorelasi antara pemerintah dengan Komnas HAM. Satu sisi, Komnas HAM berharap simpatisan hanya mendapat hukuman penjara, di sisi lain pemerintah sedang gencar melakukan program deradikalisasi untuk menekan jumlah terorisme di Indonesia. Oleh sebab itu, penulis mencoba membandingkan dua pendapat tersebut melalui konsep maslahah.

\section{B. Metode Penelitian}

Metode penelitian yang dipakai adalah kualitatif - deskriptif dengan jenis penelitian pustaka. Penelitian pustaka merupakan salah satu metode penelitian dengan cara pencatatan dan pemilahan data yang sudah berbentuk dokumen. ${ }^{4}$ Dikategorikan sebagai penelitian pustaka karena data yang digunakan merupakan data sekunder berupa berita online, jurnal, buku dan aturan perundang - undangan. $^{5}$ Data yang diperoleh kemudian dianalisis menggunakan teori maqhasid al-Syariah Jasser Auda dan teori - teori hak

\footnotetext{
${ }^{3}$ Rahel Narda Chatrine, Soal WNI eks ISIS, Komnas HAM sarankan Pemerintah Lakukan Profilling, https://news.detik.com/berita/d-4892152/soal-wni-eks-isis-komnas-ham, tanggal akses 14 April 2020. hlm. 3 .

${ }^{4}$ Mestika Zen, 2008, Metode Penelitian Kepustakaan, Yayasan Obor Indonesia, Jakarta,

${ }^{5}$ Zainuddin Ali, 2011, Metodologi Penelitian Hukum, Sinar Grafika, Jakarta, hlm. 55.
} 
asasi manusia dari berbagai aturan perundang - undangan di antaranya Universal Declaration of Human Right, UUD 1945, dan Undang - Undang Nomor 39 Tahun 1999 tentang Hak Asasi Manusia (UU HAM).

\section{Pembahasan}

\section{Larangan Pulang Warga Negara Indonesia Eks ISIS Perspektif HAM}

Hak asasi manusia atau human right didefinisikan sebagai anugrah yang diberikan kepada manusia sebagai konsekuensi sebagai makhluk ciptaan Tuhan yang maha esa. ${ }^{6}$ Hak asasi manusia merupakan hak yang melekat secara kuat sebagai hakikatnya sebagai manusia. ${ }^{7}$ Hak bukanlah pemberian negara pada individu, sehingga negara hanya bertugas untuk memenuhi apa yang sudah menjadi haknya, melindungi dari intimidasi pihak lain dan menghormati untuk tidak sekali - kali mencabut pemenuhan hak tersebut tanpa suatu alasan. Meski sejarah mencatat bahwa hak asasi manusia adalah respon perilaku berbagai kelompok yang membahayakan hak, namun fitrahnya hak asasi manusia sudah ada sejak manusia itu dilahirkan.

Jimly Ashiddiqie berpendapat bahwa gagasan HAM pasca reformasi sangat jelas diatur dalam UUD 1945. Norma hukum tentang HAM terbagi menjadi berapa bagian yaitu: a. hak - hak sipil; b. hak - hak politik, sosial dan budaya; c. hak - hak khusus dan pembangunan; d. hak - hak untuk mendapat pertanggungjawaban dari negara. Hak - hak tersebut merupakan hak - hak yang wajib dipenuhi, dihormati dan dijaga oleh negara bagi seluruh warga negara Indonsia. ${ }^{8}$

Adanya HAM adalah respon terhadap banyaknya kasus pelanggaran yang menimpa seseorang sehingga apa yang semestinya diperoleh sebagai manusia itu hilang. Mengaca dari sejarah pelanggaran HAM, ada beberapa

${ }^{6}$ Osgar S Matompo, "Pembatasan terhadap Hak Asasi Manusia dalam Prespektif Keadaan Darurat", Media Hukum, Volume 21, Nomor 1, Tahun 2014, hlm. 58.

${ }^{7}$ Majda El Muhtaj, 2015, Hukum dan Hak Asasi Manusia dalam Konstitusi Indonesia, Kencana, Jakarta, hlm. 6.

${ }^{8}$ Jimly Ashiddiqie, 2006, Pengantar Ilmu Hukum Tata Negara, Sekretariat Jenderal dan Kepaniteraan Mahkamah Konstitusi RI, Jakarta, hlm. 105 - 109. 
kategori tindakan yang termasuk pelanggaran HAM yaitu genosida, ${ }^{9}$ pembunuhan di luar putusan pengadilan (arbitrary/extra yudicial killing), penyisaan, ${ }^{10}$ penghilangan dan penculikan, ${ }^{11}$ perbudakan, ${ }^{12}$ dan perlakuan diskriminatif yang tersistematis. ${ }^{13}$

Pasal 13 Ayat (2) Deklarasi Universal Hak Asasi Manusia menyebutkan bahwa "Setiap orang berhak meninggalkan suatu negeri, termasuk negerinya sendiri, dan berhak kembali ke negerinya." Ketentuan ini diperjelas dalam Pasal 26 UUD 1945 yang menyebutkann bahwa definisi warga negara adalah mereka yang memiliki status kewaraganegaraan yang sah baik yang ada di Indonesia, maupun yang berada di luar wilayah Indonesia. Status tersebut berlaku sampai individu yang bersangkutan pindah kewarganegaraan.

Ketentuan ini menjelaskan bahwa bagaimanpun alasannya, status kewarganegaraan tidak dapat dicabut tanpa persetujuan yang bersangkutan. Oleh sebab itu, yang bersangkutan masih berhak untuk mendapat perlakuan dan pemenuhan hak yang layak oleh negara. Ketentuan Pasal 1, 2, dan 3 merupaka adopsi dari DUHAM. Akan tetapi, ketentuan tersebut di Indonesia tidak berlaku bagi simpatisan ISIS.

Jimly Ashiddiqie menyebutkan bahwa ratifikasi terhadap pasal-pasal yang ada dalam DUHAM sama halnya Indonesia juga memberlakukan pasal -

\footnotetext{
${ }^{9}$ Wahyu Wirawan, "Peran Militer dalam Gerakan Massa dan Pembunuhan Massal di Jawa - Bali" Jurnal Historia, Volume 23, Nomor 2, Tahun 2013, hlm. 4 - 6.

${ }^{10}$ Amira Rahma Sabla, "Kajian Freedom of Speech and Expression dalam Perlindungan Hukum terhadap Demonstran di Indonesia", Lex Scientia Law Review, Volume 1, Nomor 01, Tahun 2017, hlm. 90.

${ }^{11}$ Edwin Tumundo, "Penyidikan Tindak Pidana Perdagangan Orang pada Tingkat Kepolisian dalam Perspektif Hak Asasi Manusia", Lex Et Societatis, Volume 6, Nomor 4, Tahun 2018, hlm. 87.

${ }^{12}$ Eko Hidayat, "Perlindungan Hak Asasi Manusia dalam Negara Hukum Indonesia", ASAS, Volume 8, Nomor 2, Tahun 2016, hlm. 82.

${ }^{13}$ Merryany B Bawole, "Kajian Hak Asasi Manusia terhadap Perlakuan Diskriminasi kepada Pekerja Seks Komersial”, Jurnal Hukum UNSRAT, Volume 21, Nomor 3, Tahun 2013, hlm. $12-13$.
} 
pasal tersebut di wilayah Indonesia. Namun dalam praktinya, tidak semua pasal yang ada dalam DUHAM diberlakukan begitu saja. ${ }^{14}$ Hal ini sesuai dengan ketentuan yang ada dalam Pasal 28J UUD 1945 bahwa pelaksanaan hak asasi manusia dibatasi dengan nilai agama, moral, dan keamanan masyarakat. Untuk itu, negara berhak melakukan tindakan pencegahan demi menjaga ketentraman dan keamanan di mayarakat.

\section{Larangan Pulang WNI Eks ISIS Perspektif Maqashid al - Syariah}

\section{Jasser Auda}

Secara etimologi kata maslahah berasal dari bahasa arab maslahah, masdar dari fi'il madzi aslahah (membuat, menjadikan dan membentuk kebaikan). Kata aslaah dalam shorfiyah merupakan turunan kalimat shalaha yang artinya baik. Sehingga kata maslahah juga bisa diartikan baik atau suatu keadaan yang jauh dari keburukan. ${ }^{15}$ Secara terminologi, maslahah adalah keadaan yang bisa diukur secara material dan non - material dan mampu meningkatkan harkat dan martabat manusia sebagai makhluk yang paling mulia. ${ }^{16}$

Imam Ghazali mendefinisikan maslahah sebagai usaha untuk menjaga dan memelihara tujuan syariat, atau yang sering disebut degan maqosid alsyariah. ${ }^{17}$ Berbeda dengan pendapat Ghazali, Imam ash - Syatibi mendefinisikan maslahah sebagai semua hal yang dibutuhkan oleh manusia baik kebutuhan jasmani maupun kebutuhan rohani. ${ }^{18}$ Hal ini agar manusia

${ }^{14}$ Jimly Ashiddiqie, op.Cit, hlm. 108.

${ }^{15}$ Ahmad bin Faris bin Zakariya, 1979, Mu'jam Maqoyiz al-Lughah, Dar al-Fikr, Beirut, hlm. 303.

${ }^{16}$ Pusat Pengkajian dan Pengembangan Ekonomi Islam, 2015, Ekonomi Islam, Radja Grafindo Persada, Jakarta, hlm. 5.

${ }^{17}$ Enden Haitami, "Perkembangan Teori Mashlahah 'Izzu Al-Dîn bin 'Abd Al-Salâm dalam Sejarah Pemikiran Hukum Islam”, Asy Syari’ah, Volume 17, Nomor 1, Tahun 2015, hlm. 31.

${ }^{18}$ Ibid., hlm. 32. 
merasakan keyamanan dan kedamaian dalam menjalankan kehidupan di dunia dan kehidupan di akhirat. ${ }^{19}$

Kajian maslahah merupakan kajian untuk memilih dasar hukum yang paling tepat dari berbagai penafsiran atas nash. Namun, antara satu nash dengan yang lain, antara satu penafsiran dengan penafsiran lain terkadang memiliki pertentangan. Dalam masalah inilah, klausul hukum ditentukan dari nash dengan dengan tingkat kemaslahatan yang lebih tinggi. Tidak hanya hukum terhadap kasus yang sudah ditentukan oleh nash, maslahah juga memiliki kiprah yang sangat luas atas kasus yang tidak ada dasar hukumnya secara tekstual. ${ }^{20}$

Untuk mengukur maslahah yang timbul karena penolakan atas kembalinya WNI eks ISIS di Indonesia, maka konsep maqashid al - syariah yang relevan adalah konsep maqashid al-syariah Jasser Auda. Upaya rekontruksi tujuan hukum Islam yang dilakukan Jasser Auda merupakan hasil pemikirannya yang menganggap bahwa konsep maqashid al-syariah klasik hanya bersifat individual (protection) dan pelestarian (prsevation). ${ }^{21}$ Konsep itu hanya berlaku berdasarkan subjektifitas dan mengabaikan kemaslahatan universal. $^{22}$

Menurut Abu Zahra, maslahah yang paling utama adalah maslahah bagi manusia. Menurut jumhur fuqaha', maslahah merupakan dalil hukum Islam. Sehingga, selama tidak diputus berdasarkan hawa nafsu dan tidak bertentangan dengan nash, maka bisa dijadikan acuan hukum. ${ }^{23}$

${ }^{19}$ Pusat Pengkajian dan Pengembangan Ekonomi Islam, op.Cit., hlm. 5.

${ }^{20}$ Ibid., hlm. 155.

${ }^{21}$ Siti Mutholingah dan Muh. Rodhi Zamzami, "Relevansi Pemikiran Maqashid Al Syari'ah Jasser Auda terhadap Sistem Pendidikan Islam Multidisipliner", Ta'limuna, Volume 7, Nomor 2, Tahun 2018, hlm. 106.

${ }^{22}$ Ibid., hlm. 107.

${ }^{23}$ Abdul Basith Junaidy, "Menimbang Maslahah Sebagai Dasar Penetapan Hukum (Kajian terhadap Pemikiran Muhammad Abu Zahrah)", Al - Qanun: Jurnal Pemikiran dan Pembaharuan Hukum Islam, Volume 18, Nomor 2, Tahun 2015, hlm. 342. 
Pemulangan simpatisan ISIS akan berdampak pada terancamnya jiwa masyarakat Indonesia. Untuk itu konsep hiftz al-nafs merupakan pertimbangan mengambil kebijakan tersebut. Menjaga hidup sama halnya dengan melakukan kewajiban yang diamanahkan oleh Allah SWT. Menjaga hidup tidak bisa diartikan secara subjektif, namun juga harus objektif. Jika perintah Allah agar manusia menjaga nyawanya, maka manusia juga memiliki kewajiban untuk menjaga nyawa orang lain. Salah satu firman Allah dalam QS. al - Isra'/17:33

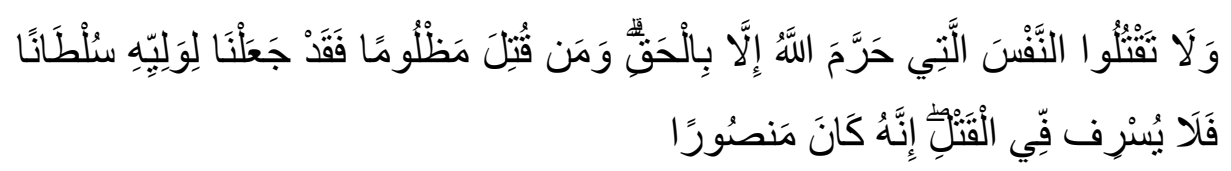

Terjemahnya:

"Dan janganlah kamu membunuh jiwa yang diharamkan Allah (membunuhnya), melainkan dengan suatu (alasan) yang benar. Dan barangsiapa dibunuh secara zalim, maka sesungguhnya Kami telah memberi kekuasaan kepada ahli warisnya, tetapi janganlah ahli waris itu melampaui batas dalam membunuh. Sesungguhnya ia adalah orang yang mendapat pertolongan."

Firman Allah tersebut adalah larangan bagi umat Islam untuk membunuh jiwa yang berhak untuk hidup (haq). Sebagai mana sabda Rasulallah Saw: "Tidak dihalalkan darah seorang muslim yang bersaksi bahwasanya tidak ada Tuhan (yang haq) selain Allah dan Muhammad adalah Rasul Allah kecuali dengan tiga alasan, yaitu: jiwa dengan jiwa, seorang laki-laki beristeri yang berbuat zina, dan orang yang meninggalkan agamanya dan memisahkan diri dari jama'ah." (HR. Al-Bukhari dan Muslim).

Salah satu tujuan syariat yang paling fundamental adalah menjaga jiwa manusia. Dasar ini bisa diterapkan apabila pemulangan WNI eks ISIS ke Indonesia ternyata membahayakan orang lain maka hal tersebut wajib ditolak. Hal ini sesuai dengan kaidah fiqh: ${ }^{24}$

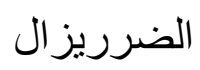

${ }^{24}$ M. Hamim HR dan Ahmad Muntaha AM, 2013, Pengantar Kaidah Fiqh Syafi'iyah, Lirboyo Press, Kediri, hlm. 7. 
Terjemahnya:

"Bahaya harus dihilangkan".

Sebagai agama yang menghendaki perdamaian, Islam selalu mengedepankan kemaslahatan dalam mengatur kehidupan manusia. Kaidah di atas adalah kaidah yang menjadi acuan umat Islam untuk menjauhi perkara yang membahayakan. Kaidah tersebut merupakan intisari dari hadits Nabi Saw:

Terjemahnya:

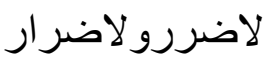

"Tidak boleh melakukan perbuatan yang membahayakan diri sendiri dan membahayakan orang lain".

Menurut Abu Zahrah, pemberlakuan syariat bagi umat Islam bertujuan untuk menciptakan kemaslahatan. ${ }^{25}$ Untuk itu, ciri khas hukum yang bisa dikategorikan dan digunakan untuk menimbang maslahah pada kasus ini harus memilik tiga ciri yaitu, upaya untuk selalu membuat kebaikan, cerminan dari penegakan hukum yang adil, dan berdampak pada kemaslahatan.

Keputusan pemerintah untuk tidak memulangkan simpatisan ISIS asal Indonesia tersebut masih menuai pro dan kontra. untuk mencapai maslahah yang hakiki maka terlebih dahulu dipertimbangkan maqashid al - syariah yang paling fundamental yaitu menjaga agama (hifdzu al - diin), jiwa (hifdzu $a l$-nafs), harta (hifdzu al-maal), akal (hifdzu al-aql) dan keturunan (hifdzu $a l-n a s l) .{ }^{26}$ Penolakan oleh pemerintah bisa dibenarkan jika seluruh WNI eks ISIS adalah pelaku terorisme, namun yang menjadi masalah adalah istri dan anak - anak yang menjadi korban kesalahan ideologi kepala keluarga.

Menurut penulis, sebagaimana dikutip dari pendapat Jasser Auda salah satu poin maqashid al-syariah yang dapat dijadikan dasar penegakan hak asasi

${ }^{25}$ Abdul Basith Junaidy, op. Cit, hlm. 339.

${ }^{26}$ Wahbah Zuhaili, 1418, Al-Tafsir al-Munir li al-Zuhail, Jilid 7, Dar al-Fikri al Mu'ashir, Damaskus, hlm. 322. 
manusia adalah hifdzu al - nafs (menjaga hidup) dan hifdzu al-nasl (menjaga keturunan) sebagai bentuk kepedulian pemerintah terhadap anak - anak dan istri - istri simpatisan ISIS tersebut. ${ }^{27}$

\section{Solusi bagi Anak dan Istri Warga Negara Indonesia Eks ISIS}

Banyak orang mengartikan radikal, radikalisme dan deradikalisasi sebagai suatu rangkaian kata yang memiliki makna sama. Padahal secara terminologi, kata - kata tersebut memiliki arti dan fungsi yang berbeda. Pertama, radikal adalah pemahaman seseorang yang berpikir secara mendalam mengenai suatu hal, baik dalam aspek sosial, ekonomi, politik bahkan hukum. Menurut KH Hasyim Muzadi, mantan ketua PBNU, pemikiran seperti boleh boleh saja dan tidak ada larangan dalam Islam. ${ }^{28}$

Kedua, Yusuf Qardhawi berpendapat bahwa ideologi radikal adalah pola pikir seseorang yang berubah dari ideologi asal karena lemahnya pengetahuan tentang hakikat agama dan sejarah mengenai teks al - Qur'an. ${ }^{29}$ Ideologi radikal atau yang dikenal dengan radikalisme adalah radikal yang sudah menjadi paham dan isme di masyarakat dan tumbuh menjadi kekuatan sehingga menimbukan teror. ${ }^{30}$ Kekuatan ini nyata, meluas dan jika tidak segera diantisipasi oleh pemerintah, akan menjadi wadah bagi korban kebijakan khususnya kaum marginal.

Ketiga, deradikalisasi memiliki arti berbeda dengan radikal dan radikalisme, meski berasal dari suku kata yang sama yaitu radikal. Deradikalisasi berasal dari bahasa Inggris “deradicalization” yaitu usaha untuk mengajari, memberi pemahaman dan langkah untuk mengembalikan sikap

${ }^{27}$ Siti Mutholingah dan Muh. Rodhi Zamzami, op.Cit., hlm. 108.

${ }^{28} \mathrm{Abu}$ Rakhmad, "Radikalisme Islam dan Upaya Deradikalisasi Paham Radikal", Jurnal Walisongo, Volume 1, Nomor 12, Tahun 2012, hlm. 82.

${ }^{29}$ Yusuf Qardhawi, 2003, Pemikiran Yusuf Qardhawi tentang Islam Radikal, terj. M. Abdul Ghoffar, Pustaka Imam Syafi'i, Bogor, hlm. 88.

${ }^{30}$ Abu Rakhmad, op.Cit., hlm. 83. 
seseorang menjadi pluralis, toleran, lunak dan moderat. ${ }^{31}$ Objek deradikalisasi adalah mengembalikan paham radikal dan radikalisme di masyarakat hingga tidak mennyebabkan konflik. Paham ini perlu untuk dideteksi sejak dini oleh pemerintah agar tidak menyebar secara luas di masyarakat.

Salah satu tujuan dari hukum Islam adalah menjaga akal. Memelihara akal bisa dilakukan dengan proses pendidikan. Menanggapi rusaknya akal kaum radikal karena doktrin yang salah mengenai agama, maka mengembalikan pemikiran harus diupayakan. Seperti yang sudah dijelaskan sebelumnya, Yusuf Qardhawi menganggap ideologi radikal sebagai ideologi seseorang yang tidak muncul secara kebetulan, melainkan ada beberapa faktor yang mempengaruhi. Ideologi radikal adalah pola pikir seseorang yang berubah dari ideologi asal karena lemahnya pengetahuan tentang hakikat agama dan sejarah mengenai teks al - Qur'an. ${ }^{32}$ Upaya deradikalisasi yang paling mungkin untuk dilaksanakan dan efektif adalah pendidikan pesantren. Sebagai lembaga yang berafilisasi dari organisasi terbesar di Indonesia (Nahdlatul Ulama), pesantren menawarkan kemaslahatan 'ammah yaitu kemaslahatan yang orientasinya adalah kesjahteraan umum di masyarakat. ${ }^{33}$

Jika pemerintah menerima pemulangan WNI eks ISIS ke Indonesia, maka program deradikalisasi bisa menjadi upaya terbaik bagi anak dan istri sebagai korban paham radikal untuk mengembalikan ideologi sesuai dengan ideologi pancasila. Namun, permasalahannya ialah ideologi bukanlah hal yang mudah diubah, karena sudah menjadi isme dan mengakar dalam pola pikir seseorang.

Penanganan radikalisme di Indonesia adalah tugas dari Badan Nasional Penanggulangan Terorisme (BNPT). Namun, mengingat radikalisme adalah suatu paham dan pola pikir, maka upaya penanganan radikalisme lebih tepat

${ }^{31}$ M. Marwan dan Jimmy. P, 2009, Kamus Hukum, Pustaka Pelajar, Yogyakarta, hlm. 519.

${ }^{32}$ Yusuf Qardhawi, 2013, Islam Radikal, PT Era Adicitra Intermedia, Solo, hlm. 88. 
dilakukan melalui program pendidikan deradikalisasi. Pendidikan deradikalisasi bertujuan untuk membentuk pola pikir seseorang yang bisa menerima keragaman di Indonesia. Dalam hal ini, pendidikan menjadi kunci utama untuk menyadarkan adanya keberagaman berbasis inklusivisme, multikulturalisme dan pluralisme di Indonesia. Tujuannya agar setiap individu memiliki wawasan agama yang toleran dan memahami konsep kebenaran yang relaltif. $^{34}$

Ideologi radikal erat kaitannya dengan dimensi agama, maka pendidikan yang baik adalah pendidikan dengan latar belakang agama yang menerima kemajemukan di Indonesia yaitu pendidikan pesantren. Menurut Yusuf Qardhawi, ada beberapa cara melalui pendidikan untuk mengatasi permasalahan radikalisme. Pertama, melalui pembelajaran agama dengan metode - metode yang telah dibuat oleh ulama untuk membentuk pemahaman mendalam tentang esensi agama guna menjadi muslim yang bijaksana dalam menyikapi perbedaan. Kedua, tidak memahami Islam secara instan, parsial dan reduktif. $^{35}$

Pendidikan yang ditawarkan pesantren memiliki tujuan yang sama dengan Islam, yaitu pendidikan yang benar - benar menggambarkan Islam secara sempurna dan membawa nilai - nilai kasih sayang bagi seluruh alam. ${ }^{36}$ Tentunya ini menjadi kontra argumen yang jelas bahwa Islam yang hakiki benar - benar bertolak belakang dengan ideologi radikal. Hal ini sebagaimana firman Allah SWT dalam QS. al - Anbiya'/21:107

${ }^{34}$ Andik Wahyun Muqoyyidin, "Membangun Kesadaran Inklusifmultikultural untuk Deradikalisasi Pendidikan Islam", Jurnal Pendidikan Islam, Volume 2, Nomor 1, Tahun 2013, hlm. 150.

${ }^{35}$ Yusuf Qardhawi, 2013, Masyarakat Berbasis Islam, terj. Abdus Salam Masykur, PT Era Adicitra Intermedia, Solo, hlm. 132.

${ }^{36}$ Ahmad Mukhtakif Billah, "Formulasi Konsep Maslahah 'Ammah Menurut Perspektif Nahdlatul Ulama dalam Konteks Kehidupan Berbangsa dan Bernegara”, Jurnal Wasathiyah, Volume 2, Nomor 1, Tahun 2018, hlm. 108. 


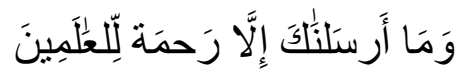

Terjemahnya:

"Dan tiadalah Kami mengutus kamu, melainkan untuk (menjadi) rahmat bagi semesta alam."

Pendidikan pesantren di Indonesia dikenal dengan keefektifannya dalam mendidik karakter bangsa. Pendidikan karakter akan memiliki dampak pada perilaku, kebiasaan, motivasi dan keterampilan seseorang. Secara perlahan, melalui pendidikan karakter di pesantren, pemikiran ekstimisme seseorang akan dididik dengan pengetahuan, kesadaran dan tekad sehingga akan membentuk pribadi yang memiliki tekad dan kemauan untuk melaksanakan nilai - nilai baik pada orang lain. Tentunya hal ini akan menjadi solusi bagi pemerintah, jika berkenan untuk memberi kesempatan WNI eks ISIS pulang kembali ke Indonesia.

Melalui pendidikan pesantren, pola pikir seseorang dapat dibangun untuk menjadi pribadi yang rendah hati, inklusif, sopan dan menghargai perbedaan. Hal ini berbeda dengan pendidikan doktrinal yang mengedepankan keangkuhan dan menganggap salah apa saja yang berbeda. Pendidikan pesantren di Indonesia mengaca pada metode pengajaran yang dilakukan oleh imam madzhab. Imam Syafi'i dalam mendidik muridnya sering mengatakan "Pendapatku benar tapi mungkin salah, pendapat orang lain salah tapi bisa saja itu yang benar". Kata-kata tersebut adalah bentuk kepedulian Imam Syafi'i agar muridnya terhindar dari sifat absolutisme dan dogmatisme yang menganggap dirinya selalu benar. ${ }^{37}$

Metode pengajaran yang diterapkan pesantren memiliki kekhasan yang tidak dimiliki oleh lembaga pendidikan lainnya. Meski zaman sudah dianggap modern dan sistem pendidikan dituntut untuk berubah dengan memanfaatkan canggihnya teknologi, pendidikan di pesantren tetap menggunakan metode

\footnotetext{
${ }^{37}$ Irwan Masduqi, "Deradikalisasi Pendidikan Islam Berbasis Khazanah Pesantren”, Jurnal Pendidikan Islam, Volume 2, Nomor 1, Tahun 2013, hlm. 10.
} 
pembelajaran yang dikenal dengan istilah sorongan wtonnan dan metode klasikal. Ciri khas kultur pendidikan pesantren antara lain; a) mendidik para santri untuk mneghormati guru, kyai dan orang lain, 2) membangun sifat kasih sayang antara senior dan junionya, 3) hukuman bagi santri biasanya bersifat non - fisik, 4) memakai pakaian Islami setiap harinya, 5) berafiliasi kultur Nahdlatul Ulama, 6) Sistem penerimaan santri tanpa seleksi, 7) biaya pendidikan yang murah. ${ }^{38}$

Untuk mencegah pemahaman yang radikal tentang Islam, santri di Pondok pesantren dibekali dengan pengetahuan - $\mathrm{p}$ ngetahuan agama yang mumpuni, diantaranya; a) memahami keilmuan Islam yang murni dari kitab kitab kuning dan literatur klasik, b) memahami ilmu gramatika seperti nahwu, mantiq, balaghah dan sharaf, c) memiliki kemampuan membaca kitab kuning dan literatur klasik dengan arti permakna dan terjemahan bebas. ${ }^{39}$

Upaya deradikalisasi akan memiliki dampak yang lebih baik bagi negara dan kehidupa simpatisan. Jika pemerintah tetap tidak menerima mereka untuk kembali, maka akan ada beberapa dampak yang dialami oleh mereka dan negara. Pertama, negara melakukan pembiaran warga negara untuk tetap berada di lingkungan yang merusak ideologi mereka. Kedua, akibat pembiaran tersebut dikhawatirkan akan membentuk bibit - bibit baru terorisme dan kemungkinan besar akan menyerang Indonesia karena adanya dendam pada pemerintah.

\section{Penutup}

Dalam hukum Islam, pemberontak atau perusak memang tidak diperkenankan untuk kembali ke suatu negara atau harus diusir dari negaranya. Namun, istri dan anak - anak bukanlah pelaku, karena itu sebaiknya tetap mendapat hak - hak sebagai warga negara Indonesia. Sedangkan, Menurut

\footnotetext{
${ }^{38}$ Nur Kholis, "Pondok Pesantren Salaf sebagai Model Pendidikan Deradikalisasi Terorisme", Akademika: Jurnal Pemikiran Islam, Volume 22, Nomor 1, Tahun 2017, hlm. 161.

${ }^{39}$ Ibid., hlm. 163.
} 
konsep maqashid Jasser Auda dan Pasal 28J UUD 1945, hak asasi manusia tidak dapat didefinisikan sebabagi pemenuhan hak secara personal. Perlu juga memperhatikan agar tidak melanggar hak orang lain. Hak asasi manusia dibatasi dengan nilai - nilai agama, norma kesusilaan, ketertiban dan keamanan masyarakat. Sejalan dengan itu, Abu Zahra berpendapat bahwa maslahah sebagai tujuan maqhasid al - syari'ah harus mementingkan kemaslahatan umum atau universal. Oleh sebab itu, penolakan pemerintah untuk memulangkan pelaku terorisme adalah kebijakan yang benar dan sesuai dengan syariat.

Radikalisme adalah permasalahan ideologi yang sulit untuk diubah dan tidak nampak secara kasat mata. Untuk itu, jika pemerintah pada akhirnya mengizinkan istri dan anak simpatisan ISIS untuk kembali ke Indonesia, program deradikalisasi harus diterapkan pada mereka. Sejauh penelusuran peneliti tentang pendidikan yang layak untuk menyelenggarakan deradikalisasi, pondok pesantren adalah lembaga pendidikan yang paling relevan. Mengingat, definisi radikalisme adalah pola pikir yang salah tentang agama, maka dari segi ilmu keagamaan, pondok pesantren merupakan yang paling mumpuni.

\section{Daftar Pustaka}

\section{Buku}

Ali, Zainuddin, 2011, Metodologi Penelitian Hukum, Sinar Grafika, Jakarta.

Ashiddiqie, Jimly, 2006, Pengantar Ilmu Hukum Tata Negara, Sekretariat Jenderal dan Kepaniteraan Mahkamah Konstitusi RI, Jakarta.

HR, M. Hamim dan Ahmad Muntaha AM, 2013, Pengantar Kaidah Fiqh Syafi'iyah, Lirboyo Press, Kediri.

Marwan, M. dan Jimmy. P, 2009, Kamus Hukum, Pustaka Pelajar, Yogyakarta. 
Pusat Pengkajian dan Pengembangan Ekonomi Islam, 2015, Ekonomi Islam, Radja Grafindo Persada, Jakarta.

Qardhawi, Yusuf, 2003, Pemikiran Yusuf Qardhawi tentang Islam Radikal, terj. M. Abdul Ghoffar, Pustaka Imam Syafi'i, Bogor.

Qardhawi, Yusuf, 2013, Islam Radikal, PT Era Adicitra Intermedia, Solo.

Qardhawi, Yusuf, 2013, Masyarakat Berbasis Islam, terj. Abdus Salam Masykur, PT Era Adicitra Intermedia, Solo.

Zakariya, Ahmad bin Faris bin, 1979, Mu’jam Maqoyiz al-Lughah, Dar al-Fikr, Beirut.

Zen, Mestika, 2008, Metode Penelitian Kepustakaan, Yayasan Obor Indonesia, Jakarta.

Zuhaili, Wahbah, 1418, Al-Tafsir al-Munir li al-Zuhail, Jilid 7, Dar al-Fikri al Mu'ashir, Damaskus.

\section{Artikel Jurnal}

Bawole, Merryany B, "Kajian Hak Asasi Manusia terhadap Perlakuan Diskriminasi kepada Pekerja Seks Komersial", Jurnal Hukum UNSRAT, Volume 21, Nomor 3, Tahun 2013.

Billah, Ahmad Mukhtakif, "Formulasi Konsep Maslahah 'Ammah Menurut Perspektif Nahdlatul Ulama dalam Konteks Kehidupan Berbangsa dan Bernegara", Jurnal Wasathiyah, Volume 2, Nomor 1, Tahun 2018.

Haitami, Enden, "Perkembangan Teori Mashlahah 'Izzu Al-Dîn bin 'Abd Al-Salâm dalam Sejarah Pemikiran Hukum Islam”, Asy Syari’ah, Volume 17, Nomor 1, Tahun 2015.

Hidayat, Eko, "Perlindungan Hak Asasi Manusia dalam Negara Hukum Indonesia", ASAS, Volume 8, Nomor 2, Tahun 2016.

Junaidy, Abdul Basith, "Menimbang Maslahah Sebagai Dasar Penetapan Hukum (Kajian terhadap Pemikiran Muhammad Abu Zahrah)”, Al - Qanun: Jurnal Pemikiran dan Pembaharuan Hukum Islam, Volume 18, Nomor 2, Tahun 2015.

Kholis, Nur, "Pondok Pesantren Salaf sebagai Model Pendidikan Deradikalisasi Terorisme", Akademika: Jurnal Pemikiran Islam, Volume 22, Nomor 1, Tahun 2017.

Masduqi, Irwan, "Deradikalisasi Pendidikan Islam Berbasis Khazanah Pesantren", Jurnal Pendidikan Islam, Volume 2, Nomor 1, Tahun 2013. 
Matompo, Osgar S, "Pembatasan terhadap Hak Asasi Manusia dalam Prespektif Keadaan Darurat", Media Hukum, Volume 21, Nomor 1, Tahun 2014.

Muhtaj, Majda El, 2015, Hukum dan Hak Asasi Manusia dalam Konstitusi Indonesia, Kencana, Jakarta.

Muqoyyidin, Andik Wahyun, "Membangun Kesadaran Inklusifmultikultural untuk Deradikalisasi Pendidikan Islam", Jurnal Pendidikan Islam, Volume 2, Nomor 1, Tahun 2013.

Mutholingah, Siti dan Muh. Rodhi Zamzami, "Relevansi Pemikiran Maqashid Al Syari'ah Jasser Auda terhadap Sistem Pendidikan Islam Multidisipliner", Ta'limuna, Volume 7, Nomor 2, Tahun 2018.

Rakhmad, Abu, "Radikalisme Islam dan Upaya Deradikalisasi Paham Radikal", Jurnal Walisongo, Volume 1, Nomor 12, Tahun 2012.

Sabla, Amira Rahma, "Kajian Freedom of Speech and Expression dalam Perlindungan Hukum terhadap Demonstran di Indonesia", Lex Scientia Law Review, Volume 1, Nomor 01, Tahun 2017.

Tumundo, Edwin, "Penyidikan Tindak Pidana Perdagangan Orang pada Tingkat Kepolisian dalam Perspektif Hak Asasi Manusia", Lex Et Societatis, Volume 6, Nomor 4, Tahun 2018.

Wirawan, Wahyu, "Peran Militer dalam Gerakan Massa dan Pembunuhan Massal di Jawa - Bali”, Jurnal Historia, Volume 23, Nomor 2, Tahun 2013.

\section{Internet}

Ariyanto, Yus, 5 jejak ISIS di Indonesia, https://www.liputan6.com/news/read, tanggal akses 21 April 2020.

Chatrine, Rahel Narda, Soal WNI eks ISIS, Komnas HAM sarankan Pemerintah Lakukan Profilling, https://news.detik.com/berita/d-4892152/soal-wni-eksisis-komnas-ham, tanggal akses 14 April 2020.

Prastia, Andika, Tok! Pemerintah Tak Akan Pulangkan WNI eks ISIS, news.detik.com/berita/d-4894943/tok-pemerintah-tak-akan-pulangkan-wnieks-isis, tanggal akses 11 April 2020. 